\title{
The influence of sagittal position of the mandible in facial attractiveness and social perception
}

Lorena Marques Ferreira de Sena로., Lislley Anne Lacerda Damasceno e Araújo²,

Arthur Costa Rodrigues Farias ${ }^{1}$. Hallissa Simplício Gomes Pereira ${ }^{3}$

DOI: $h t t p: / / d x$. doi.org/10.1590/2177-6709.22.2.077-086.oar

Objective: This study aims at comparing the perception of orthodontists, maxillofacial surgeons, visual artists and laypersons when evaluating the influence of sagittal position of the mandible — in lateral view — in facial attractiveness; at a job hiring; and in the perception of socioeconomic profile. Methods: A black male, a white male, a black female and a white female with harmonic faces served as models to obtain a facial profile photograph. Each photograph was digitally manipulated to obtain seven facial profiles: an ideal, three simulating mandibular advancement and three simulating mandibular retrusion, producing 28 photographs. These photographs were evaluated through a questionnaire by orthodontists, maxillofacial surgeons, visual artists and laypersons. Results: The anteroposterior positioning of the mandible exerted strong influence on the level of facial attractiveness, but few significant differences between the different groups of evaluators were observed $(p<0.05)$. Conclusions: The profiles pointed as the most attractive were also pointed as more favorable to be hired to a job position and pointed also as having the best socioeconomic condition.

Keywords: Mandible. Social values. Esthetics.

Objetivo: a presente pesquisa teve por objetivo comparar a percepção de ortodontistas, cirurgiões bucomaxilofaciais, artistas visuais e leigos ao avaliar a influência do posicionamento sagital da mandíbula, em vista lateral, na atratividade facial; na contratação para um emprego; e na percepção do perfil socioeconômico. Métodos: um homem negro, um homem branco, uma mulher negra e uma mulher branca com faces harmoniosas serviram como modelos para obtenção de fotografias do perfil facial. Cada fotografia obtida foi digitalmente manipulada para a obtenção de sete perfis faciais: um ideal, três simulando avanço mandibular e três simulando retrusão mandibular, originando 28 fotografias. Essas fotografias foram avaliadas, por meio de um questionário, por quatro grupos de avaliadores: ortodontistas, cirurgiões bucomaxilofaciais, artistas visuais e leigos. Resultados: o posicionamento anteroposterior da mandíbula exerceu forte influência sobre o grau de atratividade facial, porém foram observadas poucas diferenças significativas entre os diferentes grupos de avaliadores $(p<0,05)$. Conclusões: os perfis apontados como mais atraentes foram, também, os mais apontados como favoráveis à contratação para um emprego e os mais apontados como aqueles que aparentavam melhor condição socioeconômica.

Palavras-chave: Mandíbula. Percepção social. Estética.

${ }^{1}$ Post-graduation program, Department of Dentistry, Universidade Federal do Rio Grande do Norte, Natal, RN, Brazil.

${ }^{2}$ Federal University of Rio Grande do Norte, Department of Dentistry, Natal, RN, Brazil.

${ }^{3}$ Adjunct professor in Orthodontics, Department of Dentistry, Universidade Federal do Rio Grande do Norte, Natal, RN, Brazil.

» The authors report no commercial, proprietary or financial interest in the products or companies described in this article.

Submitted: August 09, 2016 - Revised and accepted: November 01, 2016
How to cite this article: Sena LMF, Damasceno e Araújo LAL, Farias ACR, Pereira HSG. The influence of sagittal position of the mandible in facial attractiveness and social perception. Dental Press J Orthod. 2017 Mar-Apr;22(2):77-86. DOI: http://dx.doi.org/10.1590/2177-6709.22.2.077-086.oar

» Patients displayed in this article previously approved the use of their facial and intraoral photographs.

Contact address: Lorena Marques Ferreira de Sena

Av. Senador Salgado Filho, no ${ }^{1787}$. Natal/RN - Brazil - CEP: 59.056-000 E-mail: lorena.mf@hotmail.com. 


\section{INTRODUCTION}

Facial esthetics has been researched for a long time. Some studies show that people with attractive dentition are considered more intelligent, more popular and more easily employed than other people with less attractive teeth. ${ }^{1,2,3}$ In addition, the desire to improve facial esthetics is one of the main reasons why people seek orthodontic treatment. ${ }^{4,5,6}$

Some authors believe that reaching the esthetic standard desired by the patient is a challenging task for dentists due to the subjective nature of the evaluation and perception of facial esthetics. ${ }^{7}$ According to Kumar et al. ${ }^{8}$ and Cochrane et al. ${ }^{9}$, professionals and laypersons perceive facial esthetics differently, with laypersons demonstrating a larger variation on what is considered to be attractive. However, there is not a consensus on the matter. Other authors ${ }^{7,10-11}$ have concluded that there is not any difference between professionals and laypersons when it comes to the perception of facial esthetics.

Among the facial structures capable of influencing the level of facial attractiveness, mandible position is highlighted. According to some authors ${ }^{12,13}$, the sagittal prominence of the mandible is an important determinant in the attractiveness of facial profile. For Naini et al, ${ }^{14}$ it is one of the facial characteristics that society tends to associate with the personality of the individual.

Considering the importance of the sagittal prominence of the mandible in facial attractiveness and the contradictory results in regard to the perception of facial esthetics by different evaluators, this study has as objective to compare the perception of orthodontists, maxillofacial surgeons, visual artists and laypersons when evaluating the influence of the sagittal positioning of the mandible, in lateral view, in facial attractiveness; in hiring the individual for a job; and in perception of the socioeconomic profile.

\section{MATERIAL AND METHODS \\ Ethical considerations}

All the criteria prescribed by Resolution 466/12 of the National Health Council (NHC), which deals with ethics in research with human beings were obeyed in implementing this study. The research project was approved by a Research Ethics Committee (REC) under number 012-04.

\section{Model selection}

Four adult individuals, being two white individuals (one male and one female) and two black individuals (one male and one female), at the average age of 25 , were selected as models. All individuals had faces considered harmonic in the vertical plane ${ }^{15}$ and in the horizontal plane. ${ }^{16}$ The individuals authorized the use of their images for scientific purposes through an Informed Consent Form.

\section{Photographs acquisition}

All photographs were taken with the individuals seated, with the Frankfurt plane and the interpupillary line parallel to the ground, using the auricular positioners of a cephalostat. The individuals were oriented to maintain their teeth in the maximum intercuspation position. The facial profile was obtained by turning the positioner to the zero degree point, where the two positioners were in the same distance to the camera, up to $85^{\circ}$, with the aim of obtaining a real outline of the profile. This position was determined through the coincidence of two previously marked points in the cephalostat, one at the base and another at the swivel mount, with the aid of a protractor. This provided the photograph of the right side facial profile, including the visualization of part of the left eyebrow. All individuals were instructed to remove makeup or facial accessories. The individuals with long hair were instructed to put the hair backwards. During the photography session, semiprofessional photographic equipment was used.

\section{Manipulation of the photographs}

The four photos with the original profiles, considered harmonic, were manipulated on a computer, using the Photoshop CS2 $9^{\circledR}$ software (Adobe Inc., San Jose, CA, USA), in order to generate four ideal profiles. Details that could distort the perception of the evaluator, such as skin spots and excessive adipose tissue in the region of the cervical mandibular angle, were corrected. The following points were marked in the photographs to standardize the alterations:

" Glabella $(G)$ : most prominent point of the forehead.

"Subnasal (Sn): limit point between the nasal septum and the cutaneous part of the superior lip.

» Pogonion $(\mathrm{Pg})$ : most anterior point of the soft tissue of the chin.

" Menton (Me): most inferior point of the soft tissue of the chin.

» Superior Lip (SL): most prominent point of the superior lip. 
» Inferior Lip (IL): most prominent point of the inferior lip.

The vertical proportions of the faces of the individuals were standardized in a manner that the proportion between middle and inferior thirds was close to 1:1. The middle third was measured in a line perpendicular to the Frankfurt plane, from $G$ point to $S n$ point, and the inferior third from the Sn point to Me point. ${ }^{15}$ The profiles were analyzed and altered, in the horizontal direction, according to angle of facial convexity. This angle, formed by a line that connects $G$ point to $S n$ point and by another that connects $\mathrm{Sn}$ point to $\mathrm{Pg}$, should be $12^{\circ}$ in adult individuals, with a standard deviation of $4^{\circ} \cdot{ }^{16}$ For this purpose, $12^{\circ}$ was the measure established for convexity angles of the four ideal profiles.

The degree of lip protrusion considered as ideal was different for white and black individuals. For white individuals, it was considered the standard lip protrusion established by Steiner. ${ }^{17}$ This author suggests that the inferior and superior lips touch the line that connects the half of the nose base to the Pogonion. For black individuals, it was considered the standard lip protrusion degree proposed by Farrow et al, ${ }^{18}$ in which the inferior and superior lips must
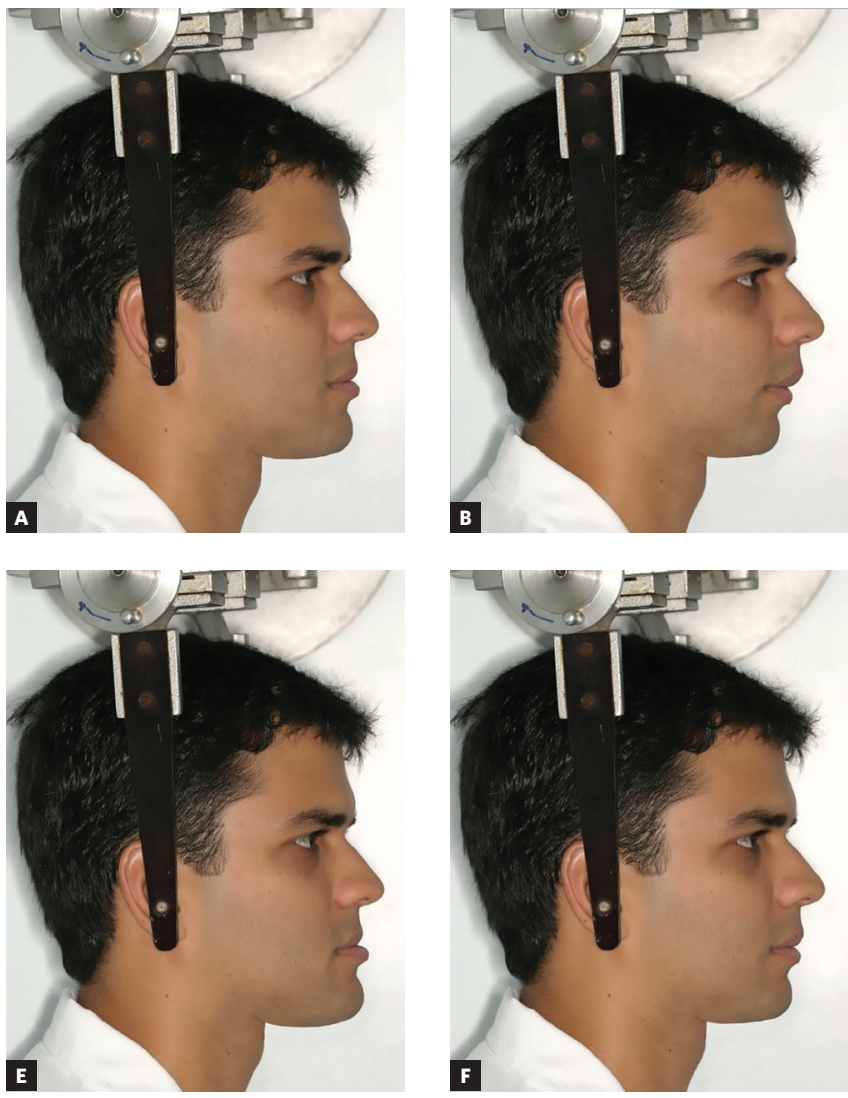

be between 3 and $6 \mathrm{~mm}$ in front of a line perpendicular to the Frankfurt plane, passing by the $\mathrm{G}$ point. These measures were set, in each profile, to produce friendly changes according to each ethnicity.

From each profile considered ideal, the Pg was advanced, by decreasing the G.Sn.Pg angle, at a rate of $4^{\circ}$, sequentially, down to $0^{\circ}$. In addition, the Pg was retracted, by increasing the G.Sn.Pg angle, at a rate of $4^{\circ}$, up to $24^{\circ}$. There were obtained, in this manner, seven profiles of each individual, one ideal, three simulating mandibular advancement and three simulating mandibular retrusion. The menton, the inferior lip and the mentolabial sulcus were advanced or retracted in a similar magnitude to Pg movement. All the modifications in the profile were made in a way that the manipulations were imperceptible. At the end, the 28 photographs of the different facial profiles were printed $(9 \times 13 \mathrm{~cm}$ size, $1200 \mathrm{dpi})$ and used to create an album with four pages of $29.5 \times 40.5 \mathrm{~cm}$ dimensions. In each page, seven photographs of the same individual were organized, three photos in the superior part, one in the middle, and three in the inferior part of the page, according to Figure 1. All photographs were identified with letters, to make easier for evaluators to answer the questionnaire.
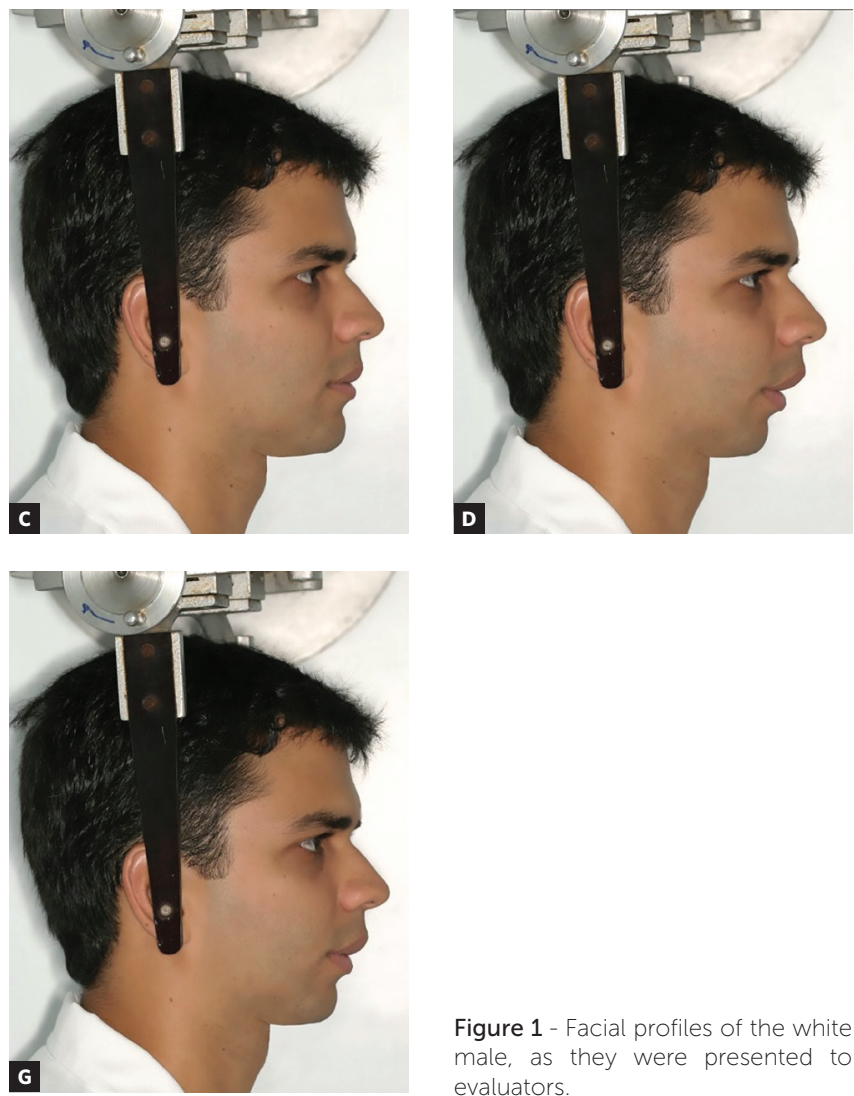

Figure 1 - Facial profiles of the white male, as they were presented to evaluators. 


\section{Selection of evaluators}

For the evaluation of the 28 facial profiles, 20 orthodontists, associated to the Associação Brasileira de Ortodontia (Brazilian Orthodontics Association); 20 maxillofacial surgeons, members of the Colégio Brasileiro de Cirurgia e Traumatologia Buco-Maxilo-Facial (Brazilian College of Oral and Maxillofacial Surgery); 20 Visual Arts students at the Universidade Federal do Rio Grande do Norte (Rio Grande do Norte Federal University); and 22 laypersons (people without academic or professional qualifications in the areas of Dentistry or Visual Arts) were selected.

\section{Evaluation of the photographs}

Together with the photo album, each evaluator received four questionnaires, one for each page of the photo album. In the first item of each questionnaire, there was a ruler (analog visual scale), so the evaluators would mark the level of attractiveness that each photo exerted on them. The marks were identified with the letter corresponding to the photograph. Each evaluator was told that it was possible to mark the ruler at any point, and it was also possible to mark two or more letters at the same point. The analog visual scale had $116 \mathrm{~mm}$, and it was written on the extreme left VERY BAD and, on the extreme right, VERY GOOD. In the center of the ruler, the word REGULAR was written. The distance $(\mathrm{mm})$ between the point marked by the evaluator and the extreme left point was measured, originating the level of attractiveness of each face. In the second item, the evaluators were asked about the relation between facial attractiveness and the feeling of trust, and had to point which of the individuals they would hire for a job position. In the third item, the evaluators were asked which one of the individuals presented a better social condition.
All the evaluators examined the album and answered the questions individually, in the same room and under the same lighting conditions. The presence of other individuals in the room was not permitted as to not influence the judgment of the evaluator. The evaluator could view the album as much as needed, until all questions were answered. All evaluators were told they could refuse to answer any question.

\section{Data analysis}

The data were treated statistically at the SPSS ${ }^{\circledR}$ (Statistical Package for Social Sciences) software.

In order to analyze the first question (Facial attractiveness), a descriptive analysis was obtained from the average and the standard deviation of each group. The Kolmogorov-Smirnov test was used to verify the distribution of data.

The variance analysis (ANOVA One-Way) was performed to verify if there were any differences among the groups and the Tukey testing to identify between which groups the differences happened. In all cases, the significance level considered was 5\%.

For the following questions, Employability and Socioeconomic condition, only descriptive analysis was performed by percentage data.

\section{RESULTS}

Table 1 shows the average and the standard deviation of the level of attractiveness that the different profiles exerted on the evaluators, regardless of the group that they belonged. Tables 2, 3, 4 and 5 show the level of attractiveness that the facial profiles of the black male, white male, black female and white female, respectively exerted on the different groups of evaluators.

Table 1 -Mean (M) and Standard Deviation (SD) of the level of attractiveness that the different facial profiles exerted on the evaluators.

\begin{tabular}{|c|c|c|c|c|}
\hline $\begin{array}{c}\text { Facial } \\
\text { convexity angle }\end{array}$ & $\begin{array}{c}\text { Black male } \\
\text { M/SD }\end{array}$ & $\begin{array}{c}\text { White male } \\
\text { M/SD }\end{array}$ & $\begin{array}{c}\text { Black female } \\
\text { M/SD }\end{array}$ & $\begin{array}{c}\text { White woman } \\
\text { M/SD }\end{array}$ \\
\hline $0^{\circ}$ & $1.07 / 0.86$ & $1.80 / 1.53$ & $0.84 / 0.66$ & $0.86 / 0.86$ \\
\hline $4^{\circ}$ & $3.55 / 2.27$ & $6.24 / 2.41$ & $2.36 / 1.49$ & $2.31 / 1.5$ \\
\hline $8^{\circ}$ & $8.21 / 2.34$ & $9.36 / 2.17$ & $6.33 / 2.62$ & $6.34 / 2.19$ \\
\hline $12^{\circ}$ & $9.41 / 2.16$ & $8.43 / 2.65$ & $9.01 / 2.11$ & $9.25 / 1.91$ \\
\hline $16^{\circ}$ & $5.66 / 2.18$ & $4.99 / 2.06$ & $6.64 / 2.39$ & $7.03 / 2.12$ \\
\hline $20^{\circ}$ & $2.32 / 1.72$ & $2.11 / 1.64$ & $3.56 / 2.20$ & $4.87 / 2.08$ \\
\hline $24^{\circ}$ & $1.12 / 1.07$ & $1.07 / 1.24$ & $1.57 / 1.22$ & $2.07 / 2.09$ \\
\hline
\end{tabular}

Confidence interval $=95 \%$. 
Table 2 -Mean and standard deviation of the level of facial attractiveness of the black male, according to each group of evaluators.

\begin{tabular}{|c|c|c|c|c|c|c|c|c|}
\hline \multirow{2}{*}{$\begin{array}{c}\text { Facial } \\
\text { convexity angle }\end{array}$} & \multicolumn{2}{|c|}{ Orthodontists } & \multicolumn{2}{|c|}{ Surgeons } & \multicolumn{2}{|c|}{ Visual artists } & \multicolumn{2}{|c|}{ Laypersons } \\
\hline & Mean & SD & Mean & SD & Mean & SD & Mean & SD \\
\hline $0^{\circ}$ & $0.74^{*}$ & 0.60 & $0.75^{\star \star}$ & 0.57 & 1.30 & 0.94 & $1.50 * * \star$ & 1.01 \\
\hline $4^{\circ}$ & 3.85 & 2.17 & 3.73 & 2.08 & 3.29 & 2.42 & 3.33 & 2.51 \\
\hline $8^{\circ}$ & $7.77^{\star}$ & 2.45 & 8.37 & 1.89 & $9.68 * * *$ & 1.46 & $7.04 * \star$ & 2.66 \\
\hline $12^{\circ}$ & $10.83^{\star}$ & 0.80 & $10.60 * \star$ & 0.95 & $8.93 * * * * * * *$ & 1.86 & $7.30 * * * * * *$ & 2.42 \\
\hline $16^{\circ}$ & 6.24 & 2.06 & 5.87 & 1.46 & 5.78 & 2.39 & 4.76 & 2.52 \\
\hline $20^{\circ}$ & 2.31 & 1.95 & 2.30 & 1.85 & 2.36 & 1.61 & 2.33 & 1.59 \\
\hline $24^{\circ}$ & $0.77^{\star}$ & 0.91 & $0.68 * *$ & 0.52 & 1.27 & 0.77 & $1.78 * * *$ & 1.51 \\
\hline
\end{tabular}

$*, * *, * * *$ Statistically significant difference among the groups of evaluators $(p<0,05)$

Table 3 -Mean and standard deviation of the level of facial attractiveness of the white male, according to each group of evaluators

\begin{tabular}{|c|c|c|c|c|c|c|c|c|}
\hline \multirow{2}{*}{$\begin{array}{l}\text { Facial } \\
\text { convexity angle }\end{array}$} & \multicolumn{2}{|c|}{ Orthodontists } & \multicolumn{2}{|c|}{ Surgeons } & \multicolumn{2}{|c|}{ Visual artists } & \multicolumn{2}{|c|}{ Laypersons } \\
\hline & Mean & SD & Mean & SD & Mean & SD & Mean & SD \\
\hline $0^{\circ}$ & 1.69 & 1.79 & 1.54 & 0.93 & 2.41 & 1.66 & 2.37 & 1.49 \\
\hline $4^{\circ}$ & 6.75 & 1.76 & 6.74 & 2.12 & 6.17 & 2.79 & 6.11 & 2.91 \\
\hline $8^{\circ}$ & $11.30 *$ & 0.58 & $10.91^{\star \star}$ & 0.74 & $8.21 * * *$ & 2.04 & $7.83 * * *$ & 2.10 \\
\hline $12^{\circ}$ & $10.23^{*}$ & 1.74 & $10.38^{* *}$ & 1.37 & $7.18 * * *$ & 2.27 & $6.75^{* * * *}$ & 2.69 \\
\hline $16^{\circ}$ & 5.05 & 1.79 & 5.44 & 1.85 & 4.73 & 2.30 & 5.56 & 2.29 \\
\hline $20^{\circ}$ & $1.71^{\star}$ & 1.21 & $1.54^{\star \star}$ & 0.99 & $3.09 * * *$ & 1.95 & 2.89 & 1.71 \\
\hline $24^{\circ}$ & $0.62^{*}$ & 0.36 & 1.20 & 1.73 & $1.73^{*}$ & 1.27 & 1.54 & 0.97 \\
\hline
\end{tabular}

*, ** Statistically significant difference among the groups of evaluators $(p<0,05)$

Table 4 - Mean and standard deviation of the level of face attractiveness of the black female, according to each group of evaluators.

\begin{tabular}{|c|c|c|c|c|c|c|c|c|}
\hline \multirow{2}{*}{$\begin{array}{l}\text { Facial } \\
\text { convexity angle }\end{array}$} & \multicolumn{2}{|c|}{ Orthodontists } & \multicolumn{2}{|c|}{ Surgeons } & \multicolumn{2}{|c|}{ Visual artists } & \multicolumn{2}{|c|}{ Laypersons } \\
\hline & Mean & SD & Mean & SD & Mean & SD & Mean & SD \\
\hline $0^{\circ}$ & $0.57^{*}$ & 0.46 & $0.57^{* *}$ & 0.43 & $1.10 * * *$ & 0.77 & $1.12^{*, * *}$ & 0.71 \\
\hline $4^{\circ}$ & 2.59 & 1.80 & 2.60 & 1.59 & 2.15 & 1.27 & 2.10 & 1.26 \\
\hline $8^{\circ}$ & 6.47 & 2.59 & 6.26 & 2.49 & 6.32 & 2.76 & 6.28 & 2.82 \\
\hline $12^{\circ}$ & $10.98^{*}$ & 0.70 & $10.68^{* *}$ & 1.02 & $7.47 * * * *$ & 1.30 & $6.92 * * *$ & 1.06 \\
\hline $16^{\circ}$ & $7.69^{*}$ & 2.34 & $8.07^{* *}$ & 2.15 & $5.44 * * *$ & 1.88 & $5.38 * * *$ & 1.89 \\
\hline $20^{\circ}$ & 3.93 & 2.39 & 3.70 & 2.05 & 3.01 & 2.14 & 3.60 & 2.29 \\
\hline $24^{\circ}$ & 1.14 & 1.19 & 1.20 & 0.98 & 1.93 & 1.19 & 2.01 & 1.29 \\
\hline
\end{tabular}

$*, * *, * * *$ Statistically significant difference among the groups of evaluators $(p<0,05)$.

Table 5 - Mean and standard deviation of the level of face attractiveness of the white female, according to each group of evaluators.

\begin{tabular}{|c|c|c|c|c|c|c|c|c|}
\hline \multirow{2}{*}{$\begin{array}{c}\text { Facial } \\
\text { convexity angle }\end{array}$} & \multicolumn{2}{|c|}{ Orthodontists } & \multicolumn{2}{|c|}{ Surgeons } & \multicolumn{2}{|c|}{ Visual artists } & \multicolumn{2}{|c|}{ Laypersons } \\
\hline & Mean & SD & Mean & SD & Mean & SD & Mean & SD \\
\hline $0^{\circ}$ & $0.37 *$ & 0.25 & $0.37 * *$ & 0.35 & $1.38 * * *$ & 0.88 & $1.34^{* * *}$ & 1.03 \\
\hline $4^{\circ}$ & 1.84 & 0.95 & 2.20 & 1.39 & 2.65 & 1.75 & 2.57 & 1.74 \\
\hline $8^{\circ}$ & 6.25 & 2.11 & 6.41 & 2.09 & 6.39 & 2.40 & 6.34 & 2.29 \\
\hline $12^{\circ}$ & $10.75 *$ & 1.16 & $10.65^{\star *}$ & 0.98 & $7.96^{* * * *}$ & 1.45 & $7.66 * * *$ & 1.37 \\
\hline $16^{\circ}$ & 6.81 & 1.82 & 7.02 & 1.77 & 7.15 & 2.53 & 7.17 & 2.38 \\
\hline $20^{\circ}$ & 4.84 & 1.50 & 4.93 & 1.42 & 4.91 & 2.66 & 4.80 & 2.57 \\
\hline $24^{\circ}$ & $1.07 * * * *$ & 1.09 & 1.04 & 0.83 & $3.09 * * *$ & 2.48 & $3.08 * * *$ & 2.42 \\
\hline
\end{tabular}

*, ** Statistically significant difference among the groups of evaluators $(p<0,05)$. 
Table 6 - Percentage of evaluators per group that chose each facial profile as the most trustworthy to hire for a job position.

\begin{tabular}{|c|c|c|c|c|c|c|c|}
\hline & $0^{\circ}$ & $4^{\circ}$ & $8^{\circ}$ & $12^{\circ}$ & $16^{\circ}$ & $20^{\circ}$ & $24^{\circ}$ \\
\hline \multicolumn{8}{|c|}{ Black male } \\
\hline Orthodontists & $0 \%$ & $0 \%$ & $10 \%$ & $90 \%$ & $0 \%$ & $0 \%$ & $0 \%$ \\
\hline Surgeons & $0 \%$ & $0 \%$ & $0 \%$ & $100 \%$ & $0 \%$ & $0 \%$ & $0 \%$ \\
\hline Visual artists & $0 \%$ & $0 \%$ & $25 \%$ & $50 \%$ & $25 \%$ & $0 \%$ & $0 \%$ \\
\hline Laypersons & $0 \%$ & $0 \%$ & $20 \%$ & $60 \%$ & $15 \%$ & $0 \%$ & $5 \%$ \\
\hline \multicolumn{8}{|c|}{ White male } \\
\hline Orthodontists & $0 \%$ & $0 \%$ & $60 \%$ & $40 \%$ & $0 \%$ & $0 \%$ & $0 \%$ \\
\hline Surgeons & $0 \%$ & $0 \%$ & $50 \%$ & $50 \%$ & $0 \%$ & $0 \%$ & $0 \%$ \\
\hline Visual artists & $0 \%$ & $35 \%$ & $50 \%$ & $15 \%$ & $0 \%$ & $0 \%$ & $0 \%$ \\
\hline Laypersons & $0 \%$ & $14 \%$ & $54 \%$ & $14 \%$ & $14 \%$ & $0 \%$ & $4 \%$ \\
\hline \multicolumn{8}{|c|}{ Black female } \\
\hline Orthodontists & $0 \%$ & $0 \%$ & $10 \%$ & $90 \%$ & $0 \%$ & $0 \%$ & $0 \%$ \\
\hline Surgeons & $0 \%$ & $0 \%$ & $10 \%$ & $90 \%$ & $0 \%$ & $0 \%$ & $0 \%$ \\
\hline Visual artists & $0 \%$ & $0 \%$ & $10 \%$ & $75 \%$ & $15 \%$ & $0 \%$ & $0 \%$ \\
\hline Laypersons & $0 \%$ & $0 \%$ & $9 \%$ & $73 \%$ & $14 \%$ & $0 \%$ & $4 \%$ \\
\hline \multicolumn{8}{|c|}{ White female } \\
\hline Orthodontists & $0 \%$ & $0 \%$ & $0 \%$ & $80 \%$ & $20 \%$ & $0 \%$ & $0 \%$ \\
\hline Surgeons & $0 \%$ & $0 \%$ & $0 \%$ & $70 \%$ & $30 \%$ & $0 \%$ & $0 \%$ \\
\hline Visual artists & $0 \%$ & $0 \%$ & $0 \%$ & $50 \%$ & $50 \%$ & $0 \%$ & $0 \%$ \\
\hline Laypersons & $0 \%$ & $4 \%$ & $10 \%$ & $41 \%$ & $37 \%$ & $4 \%$ & $4 \%$ \\
\hline
\end{tabular}

Table 7 - Percentage of evaluators that chose each profile as the one presenting better social-economic condition.

\begin{tabular}{|c|c|c|c|c|c|c|c|}
\hline & $0^{\circ}$ & $4^{\circ}$ & $8^{\circ}$ & $12^{\circ}$ & $16^{\circ}$ & $20^{\circ}$ & $24^{\circ}$ \\
\hline \multicolumn{8}{|c|}{ Black male } \\
\hline Orthodontists & $0 \%$ & $0 \%$ & $10 \%$ & $90 \%$ & $0 \%$ & $0 \%$ & $0 \%$ \\
\hline Surgeons & $0 \%$ & $0 \%$ & $30 \%$ & $70 \%$ & $0 \%$ & $0 \%$ & $0 \%$ \\
\hline Visual artists & $0 \%$ & $0 \%$ & $45 \%$ & $55 \%$ & $0 \%$ & $0 \%$ & $0 \%$ \\
\hline Laypersons & $0 \%$ & $0 \%$ & $50 \%$ & $41 \%$ & $9 \%$ & $0 \%$ & $0 \%$ \\
\hline \multicolumn{8}{|c|}{ White male } \\
\hline Orthodontists & $0 \%$ & $0 \%$ & $50 \%$ & $50 \%$ & $0 \%$ & $0 \%$ & $0 \%$ \\
\hline Surgeons & $0 \%$ & $0 \%$ & $40 \%$ & $60 \%$ & $0 \%$ & $0 \%$ & $0 \%$ \\
\hline Visual artists & $0 \%$ & $30 \%$ & $45 \%$ & $25 \%$ & $0 \%$ & $0 \%$ & $0 \%$ \\
\hline Laypersons & $0 \%$ & $14 \%$ & $59 \%$ & $23 \%$ & $4 \%$ & $0 \%$ & $0 \%$ \\
\hline \multicolumn{8}{|c|}{ Black female } \\
\hline Orthodontists & $0 \%$ & $0 \%$ & $0 \%$ & $100 \%$ & $0 \%$ & $0 \%$ & $0 \%$ \\
\hline Surgeons & $0 \%$ & $0 \%$ & $0 \%$ & $100 \%$ & $0 \%$ & $0 \%$ & $0 \%$ \\
\hline Visual artists & $0 \%$ & $0 \%$ & $20 \%$ & $70 \%$ & $10 \%$ & $0 \%$ & $0 \%$ \\
\hline Laypersons & $0 \%$ & $0 \%$ & $18 \%$ & $64 \%$ & $18 \%$ & $0 \%$ & $0 \%$ \\
\hline \multicolumn{8}{|c|}{ White female } \\
\hline Orthodontists & $0 \%$ & $0 \%$ & $0 \%$ & $90 \%$ & $10 \%$ & $0 \%$ & $0 \%$ \\
\hline Surgeons & $0 \%$ & $0 \%$ & $0 \%$ & $80 \%$ & $20 \%$ & $0 \%$ & $0 \%$ \\
\hline Visual artists & $0 \%$ & $0 \%$ & $0 \%$ & $55 \%$ & $45 \%$ & $0 \%$ & $0 \%$ \\
\hline Laypersons & $0 \%$ & $4 \%$ & $14 \%$ & $50 \%$ & $28 \%$ & $4 \%$ & $0 \%$ \\
\hline
\end{tabular}


According to these results, the anteroposterior positioning of the mandible exerts strong influence on the level of facial attractiveness, but there are few significant differences among the different groups of evaluators.

Table 6 shows the percentage of evaluators per group that chose each facial profile as the most trusted profile for a job position. In general, orthodontists and surgeons follow a similar line of thinking, agreeing, in most cases, on which profile they would hire for a job position.

Table 7 shows the percentage of evaluators per group that chose each facial profile as the profile that presented a better socioeconomic condition. In general, those profiles chosen as the most attractive were also indicated as the ones deserving the job positions.

\section{DISCUSSION}

Contemporary orthodontics has been suffering a great influence of the appeal for attractive facial esthetics. In order to ensure that the esthetic goals of an orthodontic treatment will be achieved, orthodontists must make a treatment plan substantiated by a thorough evaluation of the patient's face. By using the clinical examination of the frontal and profile views of the face, it's possible to evaluate the harmony of the structures that compose it. ${ }^{19}$

The soft tissue profile should be taken into consideration for the evaluation of underlying skeletal discrepancy itself, due to differences in the soft tissue thickness. ${ }^{20,21}$ Soft tissue outline largely determines the esthetics of the face. For this reason, the facial profile has been extensively studied in Orthodontics. ${ }^{7,22-26}$

In addition, many studies ${ }^{11,24,25,27}$ have discussed whether there is any difference in esthetic perception between professionals and laypersons, with the objective to allow the construction of treatment plans that contemplate not only the technical requirements desired by professionals, but also the needs of the patients.

The present study evaluated the influence of sagittal positioning of the mandible in facial attractiveness, from the perception of different groups of evaluators, including professionals and laypersons. Some authors have carried out similar studies. ${ }^{11,23-25}$ However, none of them had evaluated the influence of sagittal positioning of the mandible and the perception of socioeconomic profile. Another interesting aspect of the present study is the inclusion of a group of visual artists. These pro- fessionals do not have the same technical formation as orthodontists and surgeons, but they can also base their judgement on esthetics principles.

During data collection, it was opted for the use of colored photos of patients' profiles, since photographs give more realism to facial esthetics when compared to drawings of profile silhouettes. ${ }^{7}$ However, facial characteristics of the patient, such as eye color, nose size, hair, and others, may influence the judgement of the evaluator. ${ }^{23}$ For this reason, these characteristics were preserved in the different profiles with the help of Adobe Photoshop CS2 ${ }^{\circledR}$ software.

\section{Facial attractiveness}

In the first item of the questionnaire, the answers were obtained with the aid of an analog visual scale. To Maple et al, ${ }^{7}$ this scale permits a quick measurement, easy reading and greater freedom in data analysis. According to Orsini et al, ${ }^{28}$ the use of words with contrasting meanings is ideal to measure the reactions of people to specific stimuli.

As to the results, it was observed that the anteroposterior positioning of the mandible exerts strong influence on the level of facial attractiveness, but there were few significant differences among the different groups of evaluators (Tables 1 to 5). Some authors ${ }^{7,23,25}$ performed similar studies and did not observe significant differences between the groups of evaluators. McKeta et $\mathrm{al},{ }^{27}$ when comparing the perception of the results of orthodontic treatment between patients - considered as laypersons - and dentists, observed that patients have a less significantly favorable perception of their own esthetics when compared to orthodontists. In the cited study, the laypersons evaluated their own cases, while in the present study, laypersons evaluated photographs of other patients, tending, thus, to be less critical. It is important to highlight that orthodontists and surgeons did not show results with statically significant differences for any of the facial profiles analyzed, which may be attributed to the fact that only these two groups could make a judgement based on technical criteria.

When observing Table 1, it can be noticed that the extreme angulations of Class II $\left(0^{\circ}\right)$ and Class III $\left(24^{\circ}\right)$ received the lower scores, regardless of ethnicity, being that, for male individuals, the most pronounced Class II was the profile that received the lowest scores, while for the female faces, the lowest scores were attributed 
to the most pronounced Class III. Fabré et al. ${ }^{11}$ also found distinct results according to the gender of facial profiles, but the authors did not believe that the gender may influence the esthetic analysis by the evaluators. Almeida et al. ${ }^{23}$ believe that both gender and race of the facial profile may have influence on esthetic evaluation. According to Cochrane et al. ${ }^{9}$, regardless of gender, Class II is less attractive than Class III.

In regard to the faces considered ideal, the straight profile showed higher acceptance, in agreement to the majority of the studies in the literature. ${ }^{11,22-23}$ For the black male and the black female, the straight profile with an angulation of $12^{\circ}$ obtained the higher acceptance. This straight profile is characterized by low protruded lips. According to the literature ${ }^{18,29}$, black faces, when compared to white faces, are considered more attractive when presenting a slighter lip protrusion. For the white woman, the straight profile with angulation of $12^{\circ}$ also obtained higher acceptance. In the case of the white male, the straight profile with slight mandibular protrusion $\left(8^{\circ}\right)$ was the most accepted one, in agreement to the results of Almeida et al. ${ }^{23}$, that used a similar methodology, working with colored photographs and with an analog visual scale during data collection. Czarnecki et al. ${ }^{30}$, when evaluating the role of the nose, lips and chin in obtaining a balanced facial profile, also found similar results and concluded that straight profiles, with the menton slightly prominent, are more accepted to white male faces than to white female faces.

As for the evaluators, for the black male, there was a statically significant difference among the groups. According to the visual artists, the profile considered as the most harmonic was the straight one with slight mandibular protrusion $\left(8^{\circ}\right)$ and not the profile of $12^{\circ}$, which was the most chosen by other groups of evaluators. Although there was a difference between the groups, both profiles $\left(8^{\circ}\right.$ and $\left.12^{\circ}\right)$ fit in the normality clinical standard. Still regarding the black male, the visual artists agreed with the surgeons and elected the most pronounced Class II profile as the least friendly. On the other hand, orthodontists and laypersons elected the most pronounced Class III $\left(0^{\circ}\right)$ as the least friendly profile, in agreement with the findings of Romani et al, ${ }^{31}$ in which laypersons and orthodontists presented the same level of perception to sagittal changes of the mandible. For Arpino et $\mathrm{al}^{32}{ }^{32}$, orthodontists are more tolerant to changes in facial profiles than surgeons.

\section{Employability}

In general, orthodontists and surgeons follow a similar line of thinking, agreeing, in most cases, on which profile they would hire for a job position. As for visual artists and laypersons, they have shown great heterogeneity in their opinions, when each group was observed separately.

The majority of orthodontists, laypersons and visual artists agree that the black male and the black and white females with a straight profile in $12^{\circ}$ would be chosen for the job position. For the white male, the most chosen individual was that with the convexity angle in $8^{\circ}$, which represents a straight profile with slight protrusion, creating a more aggressive face with traces of seriousness. For surgeons, the profile in $12^{\circ}$ was chosen as the most favorable for hiring, regardless of race or gender. All these profiles were described as harmonic to the point of view of facial attractiveness, since for the white male the slight mandibular protrusion may indicate a peculiar beauty characteristic.

It is noted, thus, the strict relation of facial attractiveness with the easiness to get a job position. Many authors ${ }^{33-35}$ performed studies with some level of similarity and concluded that persons deemed as more attractive are also considered as more intelligent and competent, and thus, present higher chances of professional success. It is possible that these results may be associated to the assumption that intelligent people are more concerned with the impact of their image on society.

\section{Socioeconomic condition}

When evaluators were asked which of the profiles appear to have better socioeconomic condition, it was observed that, in general, the same profiles were chosen as the most attractive ones and deserving job positions.

This result presents some similarities with the findings of Kershaw, Newton and Williams, ${ }^{36}$ in which individuals with dental changes, and thus with less harmonic faces, were indicated as belonging to lower social classes, when compared to individuals without alterations. Such association may be justified by the financial investment required for dental treatment.

As for the groups of evaluators, orthodontists and maxillofacial surgeons once more followed a similar line of thought, agreeing, in majority, on which profile presented a better socioeconomic condition. 
Finally, it is important to note that there are limitations in this study, because the examiners made their judgment based only on photographs, without considering characteristics such as professional technical quality, personal skills, social class, among others. Therefore, the results presented in this study express only a first impression about the evaluated facial profiles.

\section{CONCLUSIONS}

Despite limitations of the methodology applied, it can be concluded that:

" The anteroposterior position of the mandible exerted strong influence on the level of facial attractiveness, but few significant differences were observed among the different groups of evaluators.

» The profiles pointed as the most attractive were also pointed as the most favorable to be hired for a job position, and also pointed as those that seemed to have a better socioeconomic condition.

" Orthodontists and maxillofacial surgeons showed greater concordance in their results.

1. Kokich VO, Kokich VG, Kiyak HA. Perceptions of dental professionals and laypersons to altered dental esthetics: asymmetric and symmetric situations. Am J Orthod Dentofacial Orthop. 2006 Aug:130(2):141-51.

2. Griffin AM, Langlois JH. Stereotype directionality and attractiveness stereotyping: is beauty good or is ugly bad? Soc Cogn. 2006 Apr;24(2):187-206

3. Choi WS, Lee S, McGrathe C, Samman N. Change inquality of life after combined orthodontic-surgical treatment of dentofacial deformities. Oral Surg Oral Med Oral Pathol Oral Radiol Endod. 2010;109(1):46-51.

4. Baldwin DC. Appearance and aesthetics in oral health. Community Dent Oral Epidemiol. 1980;8(5):244-56

5. Jacobson A. Psychological aspects of dentofacial esthetics and orthognathic surgery. Angle Orthod. 1984:54(1):18-35.

6. Hamdan AM. The relationship between patient, parent and clinician perceived need and normative orthodontic treatment need. Eur J Orthod 2004:26(3):265-71

7. Maple JR, Vig KWL, Beck FM, Larsen PE, Shanker S. A comparison of providers' and consumers' perceptions of facial-profile attractiveness. Am J Orthod Dentofacial Orthop. 2005;128(6):690-6.

8. Kumar S, Gandhi S, Valiathan A. Perception of smile esthetics among Indian dental professionals and laypersons. Indian J Dent Res. 2012 Mar-Apr;23(2):295.
Cochrane SM, Cunningham SJ, Hunt NP. A comparison of the perception of facial profile by the general public and 3 group of clinicians. Int J Adult Orthodon Orthognath Surg. 1999;14(4):291-5.

10. Shelly AD, Southard TE, Southard KA, Casko JS, Jakobsen JR, Fridrich KL, et al. Evaluation of profi le esthetic change with mandibular advancement surgery. Am J Orthod Dentofacial Orthop. 2000 June;117(6):630-7.

11. Fabré M, Mossaz C, Christou P, Kiliaridis S. Orthodontists' and laypersons aesthetic assessment of Class III subjects referred for orthognathic surgery. Eur J Orthod. 2009 Aug; 31(4):443-8

12. Kuroda S, Sugahara T, Takabatake S, Taketa H, Ando R, TakanoYamamoto T. Influence of anteroposterior mandibular positions on facial attractiveness in Japanese adults. Am J Orthod Dentofacial Orthop. 2009 Jan;135(1):73-8.

13. Johnston C, Hunt O, Burden D, Stevenson M, Hepper P. The influence of mandibular prominence on facial attractiveness. Eur J Orthod. 2005 Apr:27(2):129-33.

14. Naini FB. Facial aesthetics: concepts and clinical diagnosis. Oxford: WileyBlackwell; 2011

15. Proffit WR, Fields HW Jr, Sarver DM. Contemporary Orthodontics. St. Louis: Mosby Elsevier; 2012. 
16. Legan $\mathrm{HL}$, Burstone $\mathrm{CJ}$. Soft tissue cephalometric analysis for orthognathic surgery. J Oral Surg. 1980;38(10):744-51.

17. Steiner CC. Cephalometrics as a clinical tool. In: Kraus BS, Riedel RA. Vistas in Orthodontics. Philadelphia: Lea \& Febiger; 1962.

18. Farrow AL, Zarrinnia K, Azizi K. Bimaxillary protrusion in black Americans-an esthetic evaluation and the treatment considerations. Am J Orthod Dentofacial Orthop. 1993 Sept;104(3):240-50.

19. McLaren EA, Rifkin R. Macroesthetics: facial and dentofacial analysis. J Calif Dent Assoc. 2002 Nov; 30(11):839-46.

20. Burstone CJ. Integumental contour and extension patterns. Angle Orthod 1959:29 (2):93-104.

21. Subtelny JD. A longitudinal study of soft-tissue facial structures and their profile characteristics defined in relation to underlying skeletal structure. Am J Orthod. 1959 July:45 (7):481-507.

22. Soh J, Chew MT, Wong HB. Professional assessment of facial profile attractiveness. Am J Orthod Dentofacial Orthop. 2005 Aug:128(2):201-5.

23. Almeida MD, Farias ACR, Bittencourt MAV. Influence of mandibular sagittal position on facial esthetics. Dental Press J Orthod. 2010;15(2):87-96.

24. Naini FB, Donaldson AN, Cobourne MT, McDonald F. Assessing the influence of mandibular prominence on perceived attractiveness in the orthognathic patient, clinician, and layperson. Eur J Orthod. 2012 Dec;34(6):738-46.

25. Naini FB, Donaldson F, McDonald F, Cobourne MT. Assessing the influence of chin prominence on perceived attractiveness in the orthognathic patient, clinician and layperson. Int J Oral Maxillofac Surg. 2012;41(7):839-46.

26. Bullen RN, Kook Y, Kim K, Park JH. Self-perception of the facial profile: an aid in treatment planning for orthognathic surgery. J Oral Maxillofac Surg. 2014;72(4):773-8.

27. Mcketa N, Rinchuse, JD, Close, JM. Practitioner and patient perceptions of orthodontic treatment: is the patient always right? J Est Restor Dent. 2012:24(1):40-50
28. Orsini MG, Huang GJ, Kiyak HA, Ramsay DS, Bollen AM, Anderson NK, et al. Methods to evaluate profile preferences for the anteroposterior position of mandible. Am J Orthod Dentofacial Orthop. 2006 Sept;130(3):283-91.

29. Sushner NI. A photographic study of the soft-tissue profile of the Negro population. Am J Orthod. 1977 Oct;72(4):373-85

30. Czarnecki ST, Nanda RS, Currier GF. Perceptions of a balanced facial profile Am J Orthod Dentofacial Orthop. 1993 Aug:104(2):180-7.

31. Romani KL, Agahi F, Nanda R, Zernik JH. Evaluation of horizontal and vertical differences in facial profiles by orthodontists and lay people. Angle Orthod. 1993 Fall:63(3):175-82

32. Arpino VJ, Giddon DB, BeGole EA, Evans CA. Presurgical profile preferences of patients and clinicians. Am J Orthod Dentofacial Orthop. 1998 Dec;114(6):631-7.

33. Henson ST, Lindauer SJ, Gardner WG, Shroff B, Tufekci E, Best AM. Influence of dental esthetics on social perceptions of adolescents judged by peers. Am J Orthod Dentofacial Orthop. 2011 Sept;140(3):389-95.

34. Malkinson S, Waldrop TC, Gunsolley JC, Lanning SK, Sabatini R. The effect of esthetic crown lengthening on perceptions of a patient's attractiveness, friendliness, trustworthiness, intelligence, and self-confidence. J Periodontol. 2013 Aug:84(8):1126-33.

35. Pithon MM, Nascimento CC, Barbosa GC, Coqueiro RS. Do dental esthetics have any influence on finding a job? Am J Orthod Dentofacial Orthop. 2014 Oct:146(4):423-9.

36. Kershaw S, Newton JT. Williams DM. The influence of tooth colour on the perceptions of personal characteristics among female dental patients: comparisons of unmodified, decayed and 'whitened' teeth. Br Dent J. 2008 Mar 8;204(5):E9; discussion 256-7. 